\title{
The Traces of Oppression and Trauma to Ethnic Minorities in Indonesia Who Experienced Rape on the 12 May 1998 Tragedy: A Review of Literature
}

\author{
Anas Ahmadi ${ }^{1}$ \\ Universitas Negeri Surabaya, Indonesia
}

\begin{abstract}
This study explores oppression and trauma to ethnic Chinese minority women in Indonesia who experienced rape on the 12 May 1998 tragedy through literary data. The research method used was qualitative-narrative. The data source used was a novel titled $\mathrm{Mei}$ Merah (MM). The data analysis technique was carried out through stages that identified literary texts related to women's oppression from ethnic minorities; clarification of literary texts related to the oppression of women from ethnic minorities; data exposure; and data validation. The results show that ethnic Chinese women in Indonesia who experienced rape undergo trauma, impacting their psychological conditions. This was shown through Humaira, the novel's character, who experienced a phase of trauma, a phase of madness, and a phase of suicide due to rape. It happened because of a profound traumatic experience. Moreover, ethnic minority women who are raped often go abroad to remove traces because they feel ashamed and traumatized by being raped.
\end{abstract}

Keywords: ethnic minorities, literary, oppression, rape, trauma psychology, women.

Today, ethnic minorities in several countries experience oppression (Gómez, 2019; Helms et al., 2012; Mendez et al., 2020; Porter \& Williams, 2011; Townsend et al., 2020) that is a contributing factor for prolonged trauma. Jones (1997) stated that oppression related to ethnicity is classified into three categories, namely personal, cultural, institutional. McKinley et al. (2020) added that the cause of oppression of ethnic minorities is social jealousy.

In the last ten years, researchers have carried out studies about the oppression of ethnic minorities. For example, Ma (2018) reported his narrative research related to the marginalization of the Chinese government towards ethnic minorities in China, especially in terms of employment. Haller et al. (2020) exposed police oppression against ethnic minorities in Denmark. Femi-Ajao et al. (2018) examined the domestic oppression against ethnic minorities in the United Kingdom. McMahon and Seabrook (2019) examined sexual oppression and violence against ethnic minority women on campus, Mid-Atlantic, United States. Often, the government in power pays less attention to the oppression of ethnic minorities (Maruatona, 2014; Chau \& Yu, 2001). This lack of attention causes ethnic minorities to be reluctant to turn to the authorities because the government pays the most attention to the ethnic majority. Furthermore, this has resulted in the increasing oppression of ethnic minorities from year to year.

Research on ethnic minorities is very interesting because it can be viewed from various perspectives, including psychology (Verkuyten, 2018), politics (Cao, 2009), history (McDonald,

\footnotetext{
${ }^{1}$ Corresponding Author E-Mail: anasahmadi@unesa.ac.id
} 
2007), psycho-social (Oudenhoven \& Willemsen, 2020), religion (Schlee, 2017), and cultural studies (Maryland, 1978; Akinsola, 2020). Moreover, the research on ethnic minorities can also be studied from a literary perspective (Lampert, 2011). In a global context, the study of ethnic minorities reveals psychological, sociological, anthropological, and health problems (Santos \& Umaña-Taylor, 2015) experienced by ethnic minorities in various countries.

In Indonesia, one of the minorities is ethnic Chinese (Coppel, 2002; Suryadinata, 1976; Tan, 2001), who entered Indonesia around the 15th century (De Graaf \& Pigeaud, 1984) through trade routes. Ethnic Chinese in Indonesia had a long history of oppression and violence, particularly during President Suharto's rule from 1968-1998. In May of 1998, mass protests began against his New Order government, which devolved into mass violence against ethnic Chinese (Tan, 2005). As a result, President Suharto, who had led the country for 32 years, resigned. The violence against the ethnic Chinese minority included rape (Sadli \& Yentriyani, 2008), looting (Panggabean \& Smith, 2011), kidnap, and murder (Purdey, 2002).

Unfortunately, research and mass media in Indonesia have often remained "silent" about the truth of the oppression of ethnic Chinese at that time. However, one medium that speaks the truth in the literature. Often, fiction presents fact (Lewis, 2008; Oatley, 1999; van der Laan, 2010), which truth in other forms. Nowadays, "fact and fiction are no longer clearly distinguishable" (Ibsch, 1993, p. 185) so that the boundaries are blurred. Truth in fiction is sometimes an alternative to information presented in mass media because the authorities have often co-opted the mass media while an author still has independence in voicing the truth in his/her work. Oppression and violence are presented in the literature in an effort to speak the truth. Indeed, Daiyao (2002) stated that literature articulates ethnic violence through written works. The expression of oppression can not be separated from the author's voice that stands up to the truth through "fiction."

In connection with this perspective, the author as a researcher in psychology of literature/literary criticism (see, Ahmadi 2017, 2018, 2019a, 2019b, 2020a, 2020b) and cultural studies (Ahmadi, 2012) was interested in researching in-depth about the oppression against ethnic Chinese minority women in Indonesia associated with a literary context and specifically focused on the psychology of trauma. The researcher wanted to explore deeper into the psychological conditions of ethnic Chinese minority women who became victims of the 12 May 1998 tragedy through literary facts. Therefore, this study seeks to fill the gap in evidence of oppression against ethnic Chinese in Indonesia and the trauma experienced by the rape victims of ethnic Chinese women. The evidence in this article is obtained from Indonesian literature. Often, literature is a media that is not "silenced" by the government because literature is considered an aesthetic work. However, literary works also contain truths that are not revealed in research or the mass media. This study is significant because literature can speak the truth through fiction. Aside from that, this study also becomes new evidence for the public to get an alternative truth about the oppression against ethnic Chinese in Indonesia. In the context of psychological studies, a psychology researcher can explore the trauma psychology not only from empirical facts but also from the facts in literature.

\section{Literature Review}

\section{Ethnic Minorities}

Ethnicity is generally defined as a group with similarities in terms of geography, religion, sect, descent, language, cultural norms, and traditions (Carothers \& Parfitt, 2017; Dinnerstein, 
1991; Horowitz, 1985, 2011; Smedley, 1993; Varshney, 2008). Aspinall (2020) argued that the term ethnicity is "representation" because it depends on who interprets its ethnicity. Ethnicity is self-identification, perceptions, and attitudes in identity construction (Fought, 2012; McDonald, 2007). Regarding ethnicity, Ross (2017) added that taste and fate are part of ethnicity.

There are two categories of ethnic groups, namely the ethnic majority and the ethnic minority (Coyle, 2021; Farley, 2012; Szczepański, 1997; Yetman, 1999). An ethnic majority is an ethnic group that is quantified as more dominant than an ethnic minority in terms of culture, demographics, population, number of language speakers, and religion, among other determinants. An ethnic minority is an ethnic group with only a small population in terms of numbers, language speakers, religion, and culture.

\section{Trauma Psychology}

The trauma psychology is initially inseparable from Freud's view, which connects psychology to trauma experienced by a person, whether caused by rape, violence, and torture (Gold et al., 2017). The trauma psychology is related to the loss of belief in an individual that a balance exists in life. Trauma occurs when the individual loses a sense of security within himself/ herself (Van der Kolk \& Bessel, 1987, p. 12). The causes of trauma in modern society today include warfare (Crosthwaite, 2016), guilt (Brothers, 2007; Tribunella, 2010), shootings (Nader, 2015), psychosis (Morrison \& Larkin, 2015; Mueser et al., 1998), and authorities (Lipscomb, 2020). Trauma that victims experience is difficult to eliminate because trauma has already psychologically affected them.

In the context of psychological trauma, traumatized people will remember their painful experiences. This experience is also called a traumatic experience. People who have experienced trauma engage in dangerous actions, including suicide, because they feel guilty or do not feel comfortable living. Therefore, people who experience trauma need treatment from a psychologist so that they can be cured psychologically.

The current research on the trauma psychology mostly examines the victims of trauma, both in the direct, short-term, and long-term stages (Carll, 2007, p. xii). A person can be the victim of trauma due to collective crimes, individual crimes, accidents or natural disasters (Black, 1998), even terrorism and war (Jones \& Wessely, 2006). Trauma studies can be included in various other studies, for example, in the literature (Balaev, 2008) that is known as trauma literature.

\section{Psychology of Literature}

Literature is a representation of psychology (Ahmadi, 2020a; Ahmadi et al., 2019; Crews, 1970; Deliberto, 2016; Fox, 2016; Freud, 1943; Haycock \& Holland, 2006; Hogan, 2018; Ibsch et al., 2001; Kiell, 1990; Rancour-Laferriere, 1989; Rand, 2004; Rezaei \& Seyyedrezaei, 2013; Wellek \& Warren, 2019), which relates to mental processes and behavior of character through the plots. The author as a creator raises a psychological element in literature either consciously or unconsciously (Claassen, 2012; DiBattista, 2011; Kidd, 2011; Kochhar-Lindgren, 1993; Ogden \& Ogden, 2013; Philips, 2009; Picard \& Valendinova, 2017; Rogers, 1994; Ruitenbeek, 1964; Wandor, 2008; Wilson, 1995; Yothers, 2019; Zilcosky, 2016) and in a real or metaphorical form. Therefore, literature as a product of an author's creativity can be viewed from a psychological perspective. 
The study of literary psychology attracts critics who have a concern about psychology. One type of literary psychology currently emerging is the study of trauma (Tsimpouki, 2019). The current study of trauma in literature refers to Resick's (2014) view and is divided into three perspectives: psychology, behavior, and social-cognitive. In this paper, oppression is discussed in connection to trauma in the context of psychology. Caruth (1996) pioneered the study of literary psychology in the context of trauma, discussing the relationship between psychology and trauma that arises in a character's unconscious mind. Through the study of trauma, the role of literature in today's harsh world is as a medium representing traumatic language (Balaev, 2014) as empirical experience from the real world. The study of trauma psychology in the literature is related to war trauma (Brown, 2020; Stahl \& Williams, 2010; Ullah, 2020), trauma and religion (Rambo, 2010), trauma and race (Bouson, 1999; Çakirtaş, 2019), traumatic experiences (Gairola \& Jayawickrama, 2021; Horvitz, 2000; Jayawickrama, 2019), and trauma and slavery (Haehnel, 2010). Research on trauma is appealing because it provides a new alternative to the truth of trauma that is sometimes not written in the mass media.

Concerning the framework that has been described above, this study uses a literary psychology research approach focusing on the psychology of trauma. The psychology of trauma that is used to analyze the literary texts refers to the following segments, namely the initial stages of a person who has experienced trauma, causes of trauma, traumatic experiences, and posttraumatic experiences. The stages describe the traumatic experience of ethnic Chinese minority women who became rape victims in the 12 May 1998 tragedy. Specifically, this study explores the traumatic stages experienced by ethnic Chinese minority women when they were raped that are divided into the initial phase, the trauma phase, and the post-traumatic phase.

\section{Methodology}

The research method used was qualitative-narrative (Ahmadi, 2019c; Creswell \& Creswell, 2020; Currie, 2010; Denzin \& Lincoln, 2013; Lune \& Berg, 2018) because fiction studies use the narrative-descriptive technique. In this process, the researcher is a key instrument, interpreting the data in the form of literary texts or symbols (Hennink et al., 2020). In this regard, literature as a creative work is considered a psychological document and is analyzed through a psychological perspective (Das, 2018). The data source used for this study was an Indonesian novel entitled $\mathrm{Mei}$ Merah 1998 (hereinafter abbreviated as MM) by Pranoto (Pranoto, 2018) published by Yayasan Obor Indonesia (YOI).

Adapting the views of Creswell (2007), Currie (2012), Nadal and Calvo (2018), Clandinin and Connelly (2010), the narrative data used in this study were the individual experiences of the characters narrated by the author that were related to the traumatic events they had experienced. The trauma arose through dialogues, monologues, or the author's narrations. Adapting the views of Hendry et al. (2018), and Neuman (2020), the narrative data in the literature is expected to be able to create new constructions that are cosmic, colorful, and attractive to the readers.

The data analysis technique in this study adopted the qualitative psychology from Howitt and Cramer (2014) and Auerbach and Silverstein (2003). The analysis had four stages 1) identifying thoughts, actions, and narrations in the literature related to oppression against ethnic minorities; 2) classifying thoughts, actions, and narrations in the literature related to oppression against ethnic minorities; 3 ) presenting the data in a narrative-descriptive based on the researcher's interpretation as a vital instrument of the research, and 4) validating the data. At the validating stage, the researcher referred to the views of Creswell (2007), namely 1) by checking the data 
independently, the researcher repeatedly checked the theory, methods, and research results; 2) discussing with peers, the researcher discussed theory, methodology, and research results with peers in the same research field of literature; and 3) conducting discussions with the authorities, the researcher discussed and consulted the theory, methodology, and the research results to literature experts.

\section{Result and Discussion}

In MM, Pranoto, the author created a character named Humaira, a woman figure who lived from an ordinary circle. The name Humaira is an Indonesian name, not a Chinese name. However, if traced historically, she was of Chinese descent. In the past, her parents abandoned her when she was little (Pranoto, 2018). She was reared by an Indonesian woman named Inten. When she grew up, Humaira's face did not represent the face of native Indonesians but showed the face of ethnic Chinese.

\section{The First Phase: The Tragedy of the Rape of Humaira}

In MM, Humaira was a young woman who was a victim of rape on the 12 May 1998 tragedy. At first, she was in the village, but she went to Jakarta for work. During the 12 May 1998 tragedy in Jakarta, she was gang-raped by the men who were looting and burning. Mass rape in that tragedy (Himawati, 2017) was carried out collectively (Bensel \& Sample, 2017; Green, 2004) and aimed at specific ethnicities/groups, or individuals. The following description of the rape of Humaira described a painful experience.

Yes, those bastards. Very crazy. Son of a bitch. My eyes flashed, my stomach was nauseous, remembering those faces that tore my clothes and those wild genitals (Pranoto, 2018, p. 124).

The sentences above showed that the perpetrators of the rape committed cruel acts on Humaira. They not only raped Humaira but also physically hurt her. They cut Humaira's long hair and made Humaira's vagina bleed. After being raped, Humaira collapsed and was later found by the volunteer team. They, the volunteer team, took Humaira to the doctor for intensive care.

Referring to the view of Murphy (2009), rape committed by men against women is sometimes influenced by race, for example, black men rape white women. However, this view is a stereotype because rape cases occur regardless of race. Otherwise, the crime of rape can be committed by anyone and anywhere. In connection with the character Humaira who was a rape victim, she also experienced physical violence. This is in line with research conducted by Loncar et al. (2010) who examined the cases of rape committed by soldiers in Croatia, Bosnia, and Herzegovina. The research results indicates that rapists commit acts of physical violence against rape victims, such as physical torture on the female genitals and cruel beatings.

\section{Second Phase: Humaira Experiencing Trauma After Rape}

After the rape incident, Humaira became very unstable psychologically. She sometimes screamed hysterically because she still remembered and was traumatized by the incident. In the view of Eastern women, virginity is dignity for every woman. They retain virginity for their 
husbands. Therefore, when rapists take virginity, it causes the most pain and destroys a woman's mentality. The description of the character of Humaira, whose mentality was ruined, is shown in the following sentences.

Without realizing it, I immediately screamed because I was gripped by the horrendous behavior (Pranoto, 2018, p. 124).

The description above shows that Humaira was a woman who had experienced trauma due to rape. When the volunteer team helped her, she was mostly quiet and stunned. She thought of herself. She thought of her friends who were gone. She thought that she had no one in this world. It further traumatized her. In a traumatic condition, a person needs someone who can provide counseling and therapy so that she does not become more traumatized. If left untreated, trauma can lead to insanity.

In the initial stage of trauma, sometimes a woman as a rape victim experiences intense mental turmoil and conflict. At this stage, the victim must be able to go through the trauma so that it stables the mental state. In the context of $M M$, the victims who were traumatized in the initial stage did not turn to the police at all even though they wanted to so that the perpetrators can be imprisoned. However, the shame and the evidence that was difficult to obtain prevented the victims from reporting the crime. This is in line with the views of Hazelwood and Burgess (2001) that rape victims are reluctant to turn to the police. Likewise with Humaira, who did not report the crime of rape she experienced in the end.

\section{Third Phase: Humaira and Madness}

Various factors cause insanity in a person. These can include stress and trauma due to sexual harassment or the loss of the loved one (Nevid, 2014). In this regard, the character of Humaira experienced psychological distress, stress, and trauma that affected her psychological condition. She was a woman who was a rape victim. She was in such a bad condition because she did not have family in Jakarta. Therefore, there was no family that loved her and gave her empathy. Humaira became more stressed and started showing symptoms of madness. This outcome is shown in the following sentences.

Without realizing it, I grinned to answer my question: of course, rapists are difficult to catch because they would need strong evidence (Pranoto, 2018, p. 128).

The sentences above show that the character of Humaira experienced a mental shock. Her mental condition was disturbed in a psychological context because she was under intense pressure and trauma. The deep trauma due to painful experiences and cruel memories because of the rape incident made her unstable and unable to control herself. In this phase, the character of Humaira began to show the symptoms of madness, namely laughing by herself for no apparent reason and screaming loudly without being able to understand and control her mind. In terms of psychology, she experienced symptoms of schizophrenia. One symptom of madness in the schizophrenia category is an incoherent speaking ability, laughing by themselves with no apparent reason, or crying out loud (Davison \& Neale, 1990). Under certain conditions, Humaira still realized that she was starting to become unstable. These acknowledgments are shown in the following sentences. 
I am out of my mind. I am a crazy woman, that is how people call me when I am in a social institution (Pranoto, 2018, p. 49).

The sentences show Humaira was indeed in an unstable condition and experienced symptoms of the mental disorder, schizophrenia. A person with schizophrenia finds it difficult to distinguish between reality and illusion because they experience mental division. Jobe and Harrow (2010, p. 220) described that schizophrenia is caused by a psychotic condition with prolonged anxiety that causes neurosis that is left untreated. Moreover, a person with neurosis is not given medication to relieve the anxiety so it strengthens the emergence of schizophrenia. Meanwhile, having a psychotherapist to cure the psychological problems experienced by rape victims can help to reduce the level of neurosis in the victim. Thus, schizophrenia can be prevented.

When Humaira was in a state of prolonged trauma, she felt she had no friends and no support for life. Her friends were not by her side. That made her even more stressed. The high level of stress made her feel hopeless, and she even felt that God was unfair. She thought that God did not love her anymore. This description is shown in the following sentences.

\section{I am desperate. I think that Allah no longer loves me because He allowed me to get raped by those bastards (Pranoto, 2018, p. 126).}

The sentences show that Humaira was a woman who was mentally disturbed. As a religious woman who believed in God, she began to distrust God. Humaira thought that God allowed her to be raped by irresponsible men. This proved to her that God did not love her. Those symptoms showed that Humaira experienced a high level of despair and deep trauma because she had been very religious, but then she thought God did not love her.

\section{Fourth Phase: Suicide Desire}

Suicide is a complex and enigmatic action (Soper, 2019), and the causative factors are multidimensional and psychological (Shneidman et al., 1983), anthropological (Macdonald, 2007), and sociological (Douglas, 2015).

When Humaira's psychological condition was unstable, she tried to commit suicide. She, who had experienced symptoms of madness, was unable to control her mentality properly. Therefore, as a woman who was experiencing madness symptoms, she tried to commit suicide several times. A woman's suicide attempt is the last escape from the deepest scream of the heart. Women who are not strong enough to live with painful conditions often seek a "shortcut," namely suicide, leading them to death. The highest phase of trauma due to rape is suicide desire. This desire also appeared in the character of Humaira because she felt like she had no more dignity as a woman. She had nothing to be proud of because she was no longer a virgin due to rape. In this

phase, the character of Humaira attempted suicide, but it failed because someone who was helping her thwarted it. This is shown in the following sentences.

I do not care. Because I want to die. What am I living for? This always drives me to look for ways to kill myself. That is all that in my mind (Pranoto, 2018, p. 127). 
These sentences show that the character of Humaira as a woman had indeed lost control of life. What was in her mind was only death. She longed for death. She wanted to kill herself because her life was meaningless. In this respect, someone who longs for death is someone who has given up on life. Humaira, as a woman, thought that she did not want to live anymore. Humaira's willingness to end life was also caused by a schizophrenic mental condition. Faden and Citrome (2019) underlined that people with schizophrenia experience "cognitive dysfunction". The cognitive dysfunction results in emotional, functional, and also makes her antisocial. In the most severe conditions, people with schizophrenia have decreased quality of life, even long for death.

The victim of rape does not only experience psychological problems, but the victim may also become pregnant as a result of the rape crime. In connection with that, the effects of the rape of Humaira as an ethnic minority were not only trauma, madness, and death but also pregnancy. Humaira, who was in a state of madness, turned out to be pregnant. This is shown in the following sentences.

Whoa, her stomach is bloated! Maybe she is pregnant." I heard another voice, also a woman's voice. So, I let them touched my stomach. I feel weird. I can smile and mumble, "Am I pregnant? Am I carrying those bastards' fetuses?

I left my baby at the clinic due to my condition. My emotions are unstable. I can not raise my baby. Every time I look at my baby's face, I remember the fierce faces of those who raped me. I was wailing again (Pranoto, 2018, p. 9).

This explicitly shows that Humaira, as an ethnic Chinese, had experienced oppression in the form of rape. Furthermore, the effect of the rape did not stop there. Humaira became pregnant and gave birth to a child of the rape incident. When she gave birth, the trauma that she felt was still intense. She still remembered when strangers had gang-raped her. As a woman, she felt ashamed and sad because she gave birth to a child of the men who raped her. This caused prolonged trauma to her. The effect of the trauma was that Humaira entrusted the child she was born to someone else. She was unable to look after the child because she was so traumatized by the rape incident.

Ethnic Chinese women in Indonesia are physically different from the indigenous Indonesians. Ethnic Chinese women have white skin color and slant-eyes, while indigenous Indonesians have yellow skin color and wide eyes. These features have become a distinguishing feature in identifying ethnicity. The rape victims of the 12 May 1998 incident tended to be ethnic Chinese women. "They are raped, burned, and killed" (Ardianto, 2018). This was because they were ethnic minority women who were sometimes economically more prosperous than the indigenous ethnic groups, which caused social jealousy.

In this context, as a woman, the author empathizes with the psychological condition of the character of Humaira. Therefore, as an author, she showed the psychological condition of a woman who gave birth to a child who was not her own child. The child was not a product of a woman and man in love but the product of rape. In some cases, women who get pregnant because of being raped will feel frustrated and commit suicide. In Humaira's case, she was still trying to keep herself from killing herself. Rape victims who cannot bear the burden of shame and prolonged trauma will eventually commit suicide. This description is shown in the following sentences. 
The rape victims who belong to the upper economy class are generally taken abroad by their families. Not a few commit suicide because of stress, mentally unable to bear the shame and the bruising-blue trauma (Pranoto, 2018, p. 35).

The description of suicide committed by the rape victim is the fact that the woman is psychologically very traumatized by the rape incident that happened to her. In the end, she choose to commit suicide. The cases regarding rape victims during the tragedy of 12 May 1998 are rarely written in detail by the mass media. One of the few publications that tried to trace rape victims in detail was Kompas. The mass media that reported the rape victims in detail were still frightened because the ruling regime still had the power to control the mass media at that time.

Akbar's (2018) report showed that some rape victims of the 12 May 1998 tragedy were brutally murdered. One woman's genitals were stabbed with a broken glass bottle. Moreover, one rape victim who submitted a report to the United Nations (UN) did not have the chance to report because she had been killed. The woman's neck was slit, and a blunt object pierced her internal organs.

However, the actual number of women victims of rape in the 12 May 1998 incident has never been revealed in the media. Lestari (2018) reported that the rape victims were more than 150 people; Kresna (2017) stated that the number of complaints about rape incidents was 200; Yuliawati (2018) mentioned 85 rape victims. These data indicate that the rape victims are still unclear and confusing.

The factors affecting the data concerning rape victims of ethnic minority women in the 12 May 1998 tragedy were due to 1) threats from the perpetrators of the rape so that the victims did not report to the police and it what made the victims not dare to report; 2) the victims felt ashamed to report to the police because rape was a disgrace for a woman; 3 ) and the rape victims moved abroad.

The rape victims who experience forced sexual penetration feel physical and psychological pain due to rape and suffer when the rape causes a pregnancy to the victims. Due to the feelings of embarrassment and trauma, some have a sperm abortion by visiting an obstetrician. As Pranoto described it,

Some doctors are busy aborting the sperm of lecherous men in order to be failed in fertilizing the ovaries in the holy wombs that are tarnished by the devil's lust (Pranoto, 2018, p. 35).

This sentence shows that the doctors also tried to help women victims of rape. The doctor tried medically to prevent the male rapists' sperm from fertilizing the ovaries. If it happened, it caused the woman victims of rape to become pregnant. If the woman victim of rape became pregnant, the trauma level experienced by the woman victims of rape would be even higher. Pregnancy further encouraged them to commit suicide.

The rape incident of the 12 May 1998 tragedy resulted in cruel and inhuman acts. The perpetrators of the rape did not only commit the act of rape, but they also hurt the victims. As an author, Pranoto described how the rapists behaved against the women they raped. The description was shown in the following sentences. 
Among you did not only have sex with the victims but also poked the vagina with crowbars, pieces of wood, and even broken bottles. Some tore the breasts, backsides, and thighs that are innocent (Pranoto, 2018, p. 33).

Here, the author described how cruel the rape was committed against ethnic minorities through the narration of a character who was Humaira's child. Hate and anger emerged in the character when she remembered the rape incident of the 12 May 1998 tragedy. As a child who was the product of a rape, Humaira's child hated and was angry with the rapists, who were considered a coward and irresponsible. The character named Luk-Luk cursed the male rapist as a lecherous and immoral person.

\section{The Oppression Against Ethnic Minorities and the Truth in Literature}

The results of this study indicate that literature is a shred of alternative evidence to identify oppression against ethnic Chinese minority women in Indonesia. Evidence that has not been disclosed in the mass media can be extracted through literature. Literature can reveal the truth through the facts contained in it. The results of this study support the views of Hart (1962), Rockwell (1974), and Pearson (2005) who found out that literature indeed contains the truth. The facts in literature are sometimes not found in research or mass media. Therefore, facts in literature can be used as data and evidence to reveal the truth in the real world. Even more deeply, Oatley (1999) stated that facts in fiction are the actual facts.

The facts of ethnic oppression contained in the literature used in this study are in line with research conducted by Brito (1984), Peach (2007), and Hebbar (2013) who explored literature that represented the oppression of ethnic minorities. In fiction, oppression against ethnic minorities is more experienced by women. It is proven in MM, the novel that describes the oppression of ethnic Chinese minority women in Indonesia. In fact, the oppression against women occurs in various countries because women are still considered as 'second sex' (Beauvoir, 1961; Changfoot, 2009; Coblentz \& Jacobs, 2018; Sowerwine, 2000) and it makes them lose to men in several life segments, including politics, economics, and socio-cultural.

Chinese ethnic minorities that are scattered to various countries (Barabantseva, 2014), including Indonesia, have experienced oppression (see Anggraeni, 2011; Tan \& Dahana, 1997; Urban, 2013) that is known as the 12 May 1998 tragedy. At that time, there was a reform that Indonesian people wanted to change the New Order government. However, the other side of the reform was the occurrence of riots, one of which was the oppression of the ethnic Chinese minorities living in Indonesia. In that incident, ethnic Chinese minority women were the people who suffered the most persecution.

The fact in the literature work describing that ethnic Chinese minority women were being raped in the 12 May 1998 tragedy strengthened Sielke's (2009) research. The research showed data on rape cases in American literature from 1790-1990. Moreover, the literature research on rape also strengthened the researches conducted by Gunne and Brigley (2012), Horeck (2004), Mardorossian (2010) who stated that ethnic minorities in various countries were the targets of crime because they were a minority. This is one of the main causes of crime. Indeed, the authorities and justice enforcers must be able to act fairly in terms of providing legal treatment. If not, the lack of fair legal treatment will create a legal injustice between the ethnic minorities and the ethnic majorities. 


\section{Conclusion}

The narrative inquiry shows that ethnic Chinese in Indonesia were experiencing oppression. They, in this case, the ethnic Chinese women, were the victims of rape during the 12 May 1998 tragedy. Literature as fiction can indeed narrate the truths. In MM, the evidence explicitly described the ethnic Chinese women who were raped experienced prolonged trauma. The effect of rape caused women to experience the following.

First, Humaira was a woman who became the victim of rape who went through several phases: 1) remembering the rape and trauma, 2) going mad, and 3) experiencing suicidal desire. These show that the rape victims are indeed mentally disturbed. Traumatic feelings that go too deep cause madness in women. Moreover, at a higher level, women would rather commit suicide than live without dignity. Second, in the view of women, rape is the cruelest crime because it takes away dignity. Third, many ethnic Chinese women who were raped fled abroad. In this respect, ethnic Chinese women disappeared from Indonesia because they felt ashamed and traumatized by the rape incident that happened to them. Moreover, this was done so that they would avoid the threat of the rape perpetrators. Fourth, some ethnic Chinese women became pregnant due to rape in the 12 May 1998 tragedy. Due to shame and trauma, they could not raise their child because the child was not the product of their love. They entrusted their child to someone else.

This study was only focused on the oppression of ethnic Chinese minority women in Indonesia using the novel as data sources. This study as interdisciplinary research provided a new color in terms of the study of the oppression against ethnic Chinese minority women in Indonesia using ethnic perspectives, the psychology of trauma, and literature. This study is alternative research in exploring facts through literature. However, it is still limited to the evidence which is not comprehensive yet. Therefore, further researchers can deepen it through more comprehensive perspectives, such as social, cultural, and religious. In addition, this study is research that is viewed from the perspective of an Asian researcher. So, European or American researchers can carry out similar research using their perspectives. Thus, the results of this study can be used as a comparison material regarding the study of oppression against ethnic Chinese minority women with Asian, European, and American perspectives.

However, universally, literature as fiction does tell the truth. The truth representation in literature is not entirely intact and comprehensive because "literature is literature," which is a mixture of fiction and imagination. To dig deeper into the truth that has occurred, evidence and research that is more in-depth and reviewed from a multi-perspective are needed in order to produce comprehensive findings.

\section{Research Limitation}

This study focused on the study of ethnic Chinese minority women in Indonesia who experienced oppression in the form of rape. The data sources in this study are limited to one novel. Indeed, the research at a more comprehensive stage does require more novel data sources in which it is related to the oppression of ethnic Chinese minority women. Various data sources need to be done so that the research contributions can be more comprehensive and contribute the knowledge globally in the fields of ethnic studies, psychological studies, and literary studies. 


\section{References}

Ahmadi, A. (2012). Kajian budaya [Cultural studies]. Unesa University Press.

Ahmadi, A. (2017). Ecopsychology studies in Indonesia. Lambert Publishing.

Ahmadi, A. (2018). Tipikal manusia biofilia dan nekrofilia dalam novel Indonesia: Perspektif Ecopsychology [Typical human biophilic and necrophilic in Indonesian novel: Ecopsychology perspective]. Penelitian tidak diterbitkan. Direktorat Riset Penelitian dan Pengabdian Kepada Masyarakat [Unpublished research. Directorate of Research Research and Community Service].

Ahmadi, A. (2019a). Psikologi Jungian, film, dan sastra [Jungian psychology, film, literature]. Temalitera.

Ahmadi, A. (2019b). Teachers as psychologist: Experience in beginner level of creative writing classes using behavior modification. International Journal of Learning, Teaching \& Educational Research, 18(12), 101-115. https://doi.org/10.26803/ijlter.18.12.7

Ahmadi, A. (2019c). The use of SINTA (science and technology index) database to map the development of literature study in indonesia. International Journal of Mechanical Engineering \& Technology (IJMET), 10 (2), 918-923.

Ahmadi, A. (2020a). Study of criminal psychology in Indonesian literature. International Journal of Criminology \& Sociology, 9, 1285-1291. https://doi.org/10.6000/19294409.2020.09.147

Ahmadi, A. (2020b). Promoting personality psychology through literary learning: An appreciative-reflective study. International Journal of Innovation, Creativity \& Change, 11(7), 529-540.

Ahmadi, A., Ghazali, A. S., Dermawan, T., \& Maryaeni. (2019). Ecopsychology and psychology of literature: Concretization of human biophilia that loves the environment in two Indonesian novels. International Journal of Literary Humanities, 17(1), 47-59. http://doi.org/10.18848/2327-7912/CGP/v17i01/47-59

Akbar, C. (2018). Cerita pemerkosaan, kisah yang lenyap dari tragedi Mei 1998 [A rape story, a story that disappeared from the May 1998 tragedy]. https://nasional.tempo.co/read/1088332/cerita-pemerkosaan-kisah-yang-lenyap-daritragedi-mei-1998/full\&view $=$ ok

Akinsola, I. T. (2020). Nollywood Reception Preferences among Selected Multilingual Nigerian Undergraduates in the University of Ibadan: Does Ethnicity Still Matter?. American Journal of Qualitative Research, 4(1), 38-48. https://doi.org/10.29333/ajqr/8210

Anggraeni, D. (2011). Does multicultural Indonesia include its ethnic Chinese? Wacana, 13(2), 256-278.

Ardianto, R. (2018). Pemerkosaan massal, 1998 pil pahit perempuan Tionghoa [Mass rape, 1998 Chinese women's bitter pill]. Alina.id. https://www.alinea.id/nasional/pemerkosaan-massal1998-pil-pahit-perempuan-tionghoa-b1Uzn9b7x

Aspinall, P. J. (2020). Ethnic/racial terminology as a form of representation: A critical review of the lexicon of collective and specific terms in use in Britain. Genealogy, 4(87), 1-14.

Auerbach, C. F., \& Silverstein, L. B. (2003). Qualitative data: An introduction to coding and analysis. New York University Press.

Balaev, M. (2008). Trends in literary trauma theory. Mosaic: An Interdisciplinary Critical Journal, 41(2), 149-166. https://www.jstor.org/stable/i40167319 
Balaev, M. (2014). Literary trauma theory reconsidered. In M. Balaev (Ed.), Contemporary approaches in literary trauma theory (pp. 1-14). Palgrave Macmillan.

Barabantseva, E. (2014). Overseas Chinese, ethnic minorities, and nationalism: De-centering China. Routledge.

Beauvoir, S. (1961). The second sex. Bantam Books.

Bensel, T., \& Sample, L. L. (2017). Collective sexual violence in Bosnia and Sierra Leone: A comparative case study analysis. International Journal of Offender Therapy \& Comparative Criminology, 61(10), 1075-1098. https://doi.org/10.1177/0306624 $\mathrm{X} 15609704$

Black, D. (1998). Psychological trauma: A developmental approach. Gaskell.

Bouson, J. B. (1999). Quiet as it's kept: Shame, trauma, and race in the novels of Toni Morrison. State University of New York Press.

Brito, S. J. (1984). Change in American Indian world views illustrated by oral narratives and contemporary poetry. Explorations in Ethnic Studies, 7(2), 27-36.

Brothers, D. (2007). Toward a psychology of uncertainty: Trauma-centered psychoanalysis. Taylor \& Francis.

Brown, S. (2020). Hemingway, trauma and masculinity: In the garden of the uncanny. Palgrave Macmillan.

Çakirtaş, O. (2019). Literature and psychology: Writing, trauma and the self. Cambridge Scholars Publishing.

Cao, H. (2009). Ethnic minorities and regional development in Asia: Reality and challenges. Amsterdam University Press.

Carll, E. K. (2007). Trauma psychology: Issues in violence, disaster, health, and illness. Praeger Publishers.

Carothers, D., \& Parfitt, C. M. (2017). Disability or Language Difference: How Do We Decide?. American Journal of Qualitative Research, 1(1), 1-12. https://doi.org/10.29333/ajqr/5788

Caruth, C. (1996). Unclaimed experience: Trauma, narrative, and history. Johns Hopkins University Press.

Changfoot, N. (2009). The second sex's continued relevance for equality and difference feminisms. European Journal of Women's Studies, 16(1), 11-31. https://doi.org/10.1177/1350506808098532

Chau, R. C. M., \& Yu, S. W. K. (2001). Social exclusion of Chinese people in Britain. Critical Social Policy, 21(1), 103-125. https://doi.org/10.1177/026101830102100103

Claassen, E. (2012). Author representations in literary reading. John Benjamins Publishing. Company.

Clandinin, D. J., \& Connelly, F. M. (2010). Narrative inquiry: Experience and story in qualitative research. Jossey-Bass Publishers.

Coblentz, J., \& Jacobs, B. (2018). Mary daly's the church and the second sex after fifty years of us Catholic feminist theology. Theological Studies, 79(3), 543-565. https://doi.org/10.1177/0040563918784781

Coppel, C. A. (2002). Studying ethnic Chinese in Indonesia. Singapore Society of Asian Studies. Coyle, J. J. (2021). Russia's interventions in ethnic conflicts: The case of Armenia and Azerbaijan. Palgrave.

Creswell, J. W. (2007). Qualitative inquiry and research design: Choosing among five traditions. Sage Publications. 
Creswell, J. W., \& Creswell, J. D. (2020). Research design: Qualitative, quantitative, and mixed methods approaches. Sage Publications.

Crews, F. C. (1970). Psychoanalysis and literary process. Winthrop Publishers.

Crosthwaite, P. (2016). Trauma, postmodernism and the aftermath of world war II. Palgrave Macmillan.

Currie, M. (2010). About time: Narrative, fiction and the philosophy of time. Edinburgh University Press.

Daiyao, K. (2002). "Honourable resolutions": Gendered violence, ethnicity, and the nation. Alternatives: Global, Local, Political, 27(2), 219-247. https://doi.org/10.1177/ 030437540202700205

Das, B. K. (2018). Twentieth century literary criticism. Atlantic Publishers

Davison, G. C., \& Neale, J. M. (1990). Abnormal psychology: An experimental clinical approach. Wiley.

De Graaf, H. J., \& Pigeaud, G. (1984). Chinese Muslims in Java in the 15th and 16th centuries: The Malay annals of Semarang and Cerbon. Monash University Press.

Denzin, N. K., \& Lincoln, Y. S. (2013). The landscape of qualitative research. Sage Publications.

DiBattista, M. (2011). Novel characters: A Genealogy. John Wiley \& Sons.

Dinnerstein, L. (1991). Antisemitism in America. Oxford University Press.

Douglas, J. D. (2015). Social meanings of suicide. Princeton University Press.

Faden, J., \& Citrome, L. (2019). Resistance is not futile: Treatment-refractory schizophrenia overview, evaluation and treatment. Expert Opinion on Pharmacotherapy, 20(1)1124. https://doi.org/10.1080/14656566.2018.1543409

Farley, J. E. (2012). Majority-minority relations. Prentice Hall.

Femi-Ajao, O., Kendal, S., \& Lovell, K. (2018). A qualitative systematic review of published work on disclosure and help-seeking for domestic violence and abuse among women from ethnic minority populations in the UK. Ethnicity \& Health, 25(6),1-15. https://doi.org/10.1080/13557858.2018.1447652

Fought, C. (2012). Language and Ethnicity. Cambridge University Press.

Fox, A. (2016). Speaking pictures: Neuropsychoanalysis and authorship in film and literature. Indiana University Press.

Freud, S. (1943). A general introduction to psychoanalysis. Liveright Publishing Corporation.

Gairola, R. K., \& Jayawikrama, S. (2021). Memory, trauma, Asia: Oriental affect in contemporary literature and culture. Routledge.

Gold, S. N., Cook, J. M., \& Dalenberg, C. J. (Eds.). (2017). APA handbook of trauma psychology: Volume 1, Foundation in knowledge. American Psychological Association

Gómez, J. M. (2019). Isn't it all about victimization? (Intra)cultural pressure and cultural betrayal trauma in ethnic minority college women. Violence Against Women, 25(10), 1211-1225. https://doi.org/10.1177/1077801218811682

Green, J. L. (2004). Uncovering collective rape: A comparative study of political sexual violence. International Journal of Sociology 34(1), 97-116.

Gunne, S., \& Brigley, T. Z. (2012). Feminism, literature and rape narratives: Violence and violation. Taylor and Francis.

Haehnel, B. (2010). Slavery in art and literature: Approaches to trauma, memory and visuality. Berlin Frank \& Timme. 
Haller, B. M., Kolind, T., Hunt, G., \& Søgaard, T. F. (2020). Experiencing police violence and insults: Narratives from ethnic minority men in Denmark. Nordic Journal of Criminology, 21(2), 170-185. https://doi.org/10.1080/2578983x.2020.1839712

Hart, D. V. (1962). Overseas Americans in Southeast Asia: Fact in fiction. Practical Anthropology, 9(2), 60-84. https://doi.org/10.1177/009182966200900202

Haycock, D. A., \& Deliberto, T. (2016). Characters on the couch: Exploring psychology through literature and film. Greenwood.

Hazelwood, R. R., \& Burgess, W. (2001). Practical aspects of rape investigation: A multidisciplinary approach. CRC Press.

Hebbar, R. J. (2013). Modeling minority women: Heroines in African and Asian American fiction. Hoboken: Taylor and Francis.

Helms, J. E., Nicolas, G., \& Green, C. E. (2012). Racism and ethnoviolence as trauma: Enhancing professional and research training. Traumatology, 18(1), 65-74. https://doi.org/10.1177/1534765610396728

Hendry, P. M., Mitchell, R., \& Eaton, P. W. (2018). Troubling method: Narrative research as being. Peter Lang.

Hennink, M., Hutter, I., \& Bailey, A. (2020). Qualitative research methods. Sage Publications.

Himawati, C. L. (2017). Opresi berlapis perempuan etnis Tionghoa: Pemerkosaan massal terhadap perempuan etnis Tionghoa dalam Tragedi Mei 1998 di Jakarta [Layered oppression of ethnic Chinese women: Mass rapes of ethnic Chinese women in the May 1998 Tragedy in Jakarta]. Jurnal Politik, 2(2), 338-364.

Hogan, P. C. (2018). Literature and emotion. Routledge.

Holland, N. N. (2006). Holland's guide to psychoanalytic psychology and literature and psychology. Oxford University Press.

Horeck, T. (2004). Public rape: Representing violation in fiction and film. Routledge.

Horowitz, D. (1985). Ethnic groups in conflict. University of California Press.

Horowitz, D. L. (2011). Ethnic groups in conflict: With a new preface. University of California Press.

Horvitz, D. M. (2000). Literary trauma: Sadism, memory, and sexual violence in American women's fiction. State University of New York Press.

Howitt, D., \& Cramer, D. (2014). Introduction to research methods in psychology. Pearson

Ibsch, E. (1993). Fact and fiction in postmodernist writing. Journal of Literary Studies, 9(2), 185193, https://doi.org/10.1080/02564719308530040

Ibsch, E., Schram, D. H., \& Steen, G. (2001). The psychology and sociology of literature: In honor of Elrud Ibsch. John Benjamins Publishing Company.

Jayawickrama, S. (2019). Trauma, memory, and healing in Asian literature and culture. Springer.

Jobe, T. H., \& Harrow, M. (2010). Schizophrenia course, long-term outcome, recovery, and prognosis. Current Directions in Psychological Science, 19(4), 220-225. https://doi.org/10.1177/0963721410378034

Jones, E., \& Wessely, S. (2006). Psychological trauma: A historical perspective. Psychiatry, 5(7), 217-220. https://doi.org/10.1053/j.mppsy.2006.04.011

Jones, J. (1997). Prejudice and racism (2nd ed.). McGraw-Hill.

Kidd, K. B. (2011). Freud in Oz: At the intersections of psychoanalysis and children's literature. University of Minnesota Press.

Kiell, N. (1990). Psychoanalysis, psychology, and literature: A bibliography. Scarecrow. 
Kochhar-Lindgren, G. (1993). Narcissus transformed: The textual subject in psychoanalysis and literature. Pennsylvania State University Press.

Kresna, M. (2017). Ita F Nadia: Perkosaan masal itu terjadi [Ita F Nadia: Mass rape happened]. https://tirto.id/perkosaan-massal-1998-itu-terjadi-cpa2

Lampert, J. (2011). Children's fiction about 9/11:Ethnic, heroic and national identities. Routledge.

Lestari, S. (2018). Perkosaan Mei 1998 'tak pernah terungkap, tak pernah dituntaskan' [May 1998 rape 'never revealed, never resolved']. BBC News Indonesia. https://www.bbc.com/indonesia/dunia-44134808

Lewis, N. (2008). Facts and fiction: Literary instructions on public school integration in Ernest Hill's satisfied with nothin'. Law \& Literature, 20(1), 115-126. https://doi.org/ 10.1525/lal.2008.20.1.115

Lipscomb, A. E. (2020). You have the right to exclaim your pain: Honoring black familial voices impacted by police induced trauma in the United States. Journal of Ethnic and Cultural Studies, 7(1), 131-142. http://dx.doi.org/10.29333/ejecs/296

Loncar, M., Henigsberg, N., \& Hrabac, P. (2010). Mental health consequences in men exposed to sexual abuse during the war in Croatia and Bosnia. Journal of Interpersonal Violence, 25(2), 191-203. https://doi.org/10.1177/0886260509334288

Lune, H., \& Berg, B. L. (2018). Qualitative research methods for the social sciences. Pearson India Education Services Pvt.

Ma, X. (2018). Ethnic minority empowerment and marginalization: Yi labour migrants outside China's autonomous regions. China Information, 33(2), 146-164. https://doi.org/10. 1177/0920203X18800192

Macdonald, C. J. H. (2007). Uncultural behavior: An anthropological investigation of suicide in the southern Philippines. University of Hawai'i Press.

Mardorossian, C. M. (2010). Rape by proxy in contemporary Caribbean women's fiction. In S. Gunne \& Z. B. Thompson (Eds.), Violence and Violation (pp. 23-37). Routledge.

Maruatona, T. (2014). Lifelong learning for social inclusion of ethnic minorities in Botswana. Education. Citizenship and Social Justice, 10(1), 37-54. https://doi.org/10.1177/ 1746197914558397

Maryland. (1978). Ethnic and cultural studies: A bibliography. Office of School Media Services.

McDonald, J. (2007). American ethnic history: Themes and perspectives. Rutgers University Press.

McKinley, C. E., Boel-Studt, S., Renner, L. M., Figley, C. R., Billiot, S., \& Theall, K. P. (2020). The historical oppression scale: Preliminary conceptualization and measurement of historical oppression among indigenous peoples of the United States. Transcultural Psychiatry, 57(2), 288-303. https://doi.org/10.1177/1363461520909605

McMahon, S., \& Seabrook, R. C. (2019). Reasons for nondisclosure of campus sexual violence by sexual and racial/ethnic minority women. Journal of Student Affairs Research \& Practice, 57(4), 417-431. https://doi.org/10.1080/19496591.2019.1662798

Mendez, L., Mozley, M. M., \& Kerig, P. K. (2020). Associations among trauma exposure, callousunemotionality, race or ethnicity, and gang involvement in justice-involved youth. Criminal Justice \& Behavior, 47(4), 457-469. https://doi.org/10.1177/ 0093854819897940

Morrison, A. P., \& Larkin, W. (2015). Trauma and hearing voices. In W. Larkins, \& A. P. Morrison (Eds.), Trauma and psychosis: New directions for theory and therapy (pp. 162-194). Routledge. 
Mueser, K. T., Goodman, L. B., Trumbetta, S. L., Rosenberg, S. D., Osher, F. C., Vidaver, R., Auciello, P., \& Foy, D. W. (1998). Trauma and posttraumatic stress disorder in severe mental illness. Journal of Consulting \& Clinical Psychology, 66(3), 493-499. https://doi.org/10.1037//0022-006x.66.3.493

Murphy, M. J. (2009). Can "men" stop rape?: Visualizing gender in the "my strength is not for hurting" rape prevention campaign. Men and Masculinities, 12(1), 113-130. https://doi.org/10.1177/1097184X09331752

Nadal, B. M., \& Calvo, M. (2018). Trauma in contemporary literature: Narrative and representation. Routledge.

Nader, K. (2015). Understanding and assessing trauma in children and adolescents: Measures, methods, and youth in context. Routledge.

Neuman, W. L. (2020). Social research methods: Qualitative and quantitative approaches. Pearson Education.

Nevid, J. S. (2014). Essentials of psychology: Concepts and applications. Cengage Learning.

Oatley, K. (1999). Why fiction may be twice as true as fact: Fiction as cognitive and emotional simulation. Review of General Psychology, 3(2), 101-117. https://doi.org/10.1037/ 10892680.3.2.101

Ogden, B. H., \& Ogden, T. H. (2013). The analyst's ear and the critic's eye: Rethinking psychoanalysis and literature. Routledge.

Oudenhoven, J. P., \& Willemsen, T. M. (2020). Ethnic minorities: Social psychological perspectives. Garlan Science.

Panggabean, S. R., \& Smith, B. (2011). Explaining anti-Chinese Riots in late 20th century Indonesia. World Development, 39(2), 231-242. https://doi.org/10.1016/j.worlddev. 2009.11.036

Peach, L. (2007). Contemporary Irish and Welsh women's fiction: Gender, desire and power. University of Wales Press.

Pearson, R. C. (2005). Fact or fiction?: Narrative and reality in the Mexican telenovela. Television \& New Media, 6(4), 400-406. https://doi.org/10.1177/1527476405279863

Phillips, A. (2009). Promises, promises essays on psychoanalysis and literature. Basic Books.

Picard, A. M., \& Valendinova, K. (2017). From illiteracy to literature: Psychoanalysis and reading. Routledge.

Porter, J., \& Williams, L. M. (2011). Intimate violence among underrepresented groups on a college campus. Journal of Interpersonal Violence, 26, 3210-3224.

Pranoto, N. (2018). Mei Merah 1998 [Red May 1998]. Yayasan Obor Indonesia.

Purdey, J. (2002). Problematizing the place of victims in reformasi Indonesia a contested truth about the May 1998 violence. Asian Survey, 42(4), 605-622.

Rambo, S. (2010). Haunted (by the) gospel: Theology, trauma, and literary theory in the twentyfirst century. PMLA/Publications of the Modern Language Association of America, 125(4), 936-941. https://doi.org/10.1632/pmla.2010.125.4.936

Rancour-Laferriere, D. (1989). Russian literature and psychoanalysis. John Benjamins Publishing Company.

Rand, N. (2004). Psychoanalysis and literature. Palgrave Macmillan.

Resick, P. A. (2014). Stress and trauma. Taylor \& Francis.

Rezaei, A., \& Seyyedrezaei, S. H. (2013). The contribution of psychological theories in literary criticism. Procedia-Social and Behavioral Sciences, 84, 1908-1911. https://doi.org/10. 1016/j.sbspro.2013.07.056 
Rockwell, J. (1974). Fact in fiction: The use of literature in the systematic study of society. Routledge \& K. Paul.

Rogers, R. (1994). Self and other: Object relations in psychoanalysis and literature. New York University Press.

Ross, M. H. (2017). Cultural contestation in ethnic conflict. Cambridge University Press.

Ruitenbeek, H. M. (1964). Psychoanalysis and literature. Dutton.

Sadli, S., \& Yentriyani, A. (2008). Documentation report: Time to settle the sense of security; A step toward the fulfillment of rights for women victim of sexual violence in May 1998 Riot. National Commission on Violence against Women.

Santos, C. E., \& Umaña-Taylor, A. J. (Eds.). (2015). Studying ethnic identity: Methodological and conceptual approaches across disciplines. American Psychological Association.

Schlee, G. (2017). Difference and sameness as modes of integration: Anthropological perspectives on ethnicity and religion. Berghahn

Shneidman, E. S., Farberow, N. L., \& Litman, R. E. (1983). The psychology of suicide. Jason Aronson.

Sielke, S. (2009). Reading rape: The rhetoric of sexual violence in American literature and culture, 1790-1990. Princeton University Press.

Smedley, A. (1993). Race in North America: Origin and evolution of a worldview. Westview Press.

Soper, C. A. (2019). Evolution of suicide. Springer.

Sowerwine, C. (2000). Existentialism, resistance, and the second sex. Australian Feminist Studies, 15(33), 317-323. https://doi.org/10.1080/713611983

Stahl, D. C., \& Williams, M. (2010). Imag(in)ing the war in Japan: Representing and responding to trauma in postwar literature and film. Brill.

Suryadinata, L. (1976). Indonesian policies toward the Chinese minority under the new order. Asian Survey, 16(8), 770-787. https://doi.org/10.2307/2643578

Szczepański, M. S. (1997). Ethnic minorities \& ethnic majority: Sociological studies of ethnic relations in Poland. Uniwersytetu Śląskiego.

Tan, E. K. B. (2001). From sojourners to citizens: Managing the ethnic Chinese minority in Indonesia and Malaysia. Ethnic \& Racial Studies, 24(6), 949-978. https://doi.org/10.1080/01419870120077922

Tan, M. G. (2005). Ethnic Chinese in Indonesia. Encyclopedia of diasporas, 795-808. https://doi.org/10.1007/978-0-387-29904-4_82

Tan, M. G., \& Dahana, A. (1997). The ethnic Chinese in Indonesia: Issues of identity. In L. Suryadinata (Ed.), Ethnic Chinese as southeast Asians (pp. 33-71). Palgrave Macmillan.

Townsend, T. G., Kaltman, S., Saleem, F., Coker-Appiah, D. S., \& Green, B. L. (2020). Ethnic disparities in trauma-related mental illness: Is ethnic identity a buffer? Journal of Interpersonal Violence, 35(11-12), 2164-2188. https://doi.org/10.1177/08862605 17701454

Tribunella, E. L. (2010). Melancholia and maturation: The use of trauma in American. University of Tennessee Press.

Tsimpouki, T. (2019). Agency in complicity: The aesthetics of trauma in constance fenimore Woolson's 'Miss Grief.' In O. Çakirtaş (Ed.), Literature and psychology: Writing, trauma and the self (pp. 155-174). Cambridge Scholars Publishing. 
Ullah, I. (2020). War memory, psychological trauma, and literary witnessing: Afghan cultural production in focus. Sage Open, 10(3), 1-10. https://doi.org/10.1177/ 2158244020961128

Urban, G. S. (2013). The eternal newcomer: Chinese Indonesian identity from Indonesia to the United States. LUX: A Journal of Transdisciplinary Writing and Research, 3(1), 1-19.

Van der Kolk, B. A., \& Bessel, A. (1987). Psychological trauma. Psychiatric Publishing.

Van der Laan, J. M. (2010). Frankenstein as science fiction and fact. Bulletin of Science, Technology \& Society, 30(4), 298-304. https://doi.org/10.1177/0270467610373822

Varshney, A. (2008). Ethnic conflict and civic life: Hindus and Muslims in India. Yale University Press.

Verkuyten, M. (2018). The social psychology of ethnic identity. Taylor \& Francis Group.

Wandor, M. (2008). The author is not dead, merely somewhere else: Creative writing reconceived. Palgrave Macmillan.

Wellek, R., \& Warren, A. (2019). Theory of literature. Snova.

Wilson, S. (1995). The cradle of violence: Essays on psychiatry, psychoanalysis and literature. Kingsley.

Yetman, N. R. (1999). Majority and minority: The dynamics of race and ethnicity in American life. Allyn and Bacon.

Yothers, B. (2019). Melville's mirrors: Literary criticism and America's most elusive author. Camden House.

Yuliawati, P. S. (2018). Deretan kisah mengerikan pemerkosaan massal Mei 1998 [A series of gruesome stories of mass rape in May 1998]. CNN Indonesia. https://www.cnnindonesia.com/nasional/20160519124757-20-131898/deretan-kisahmengerikan-pemerkosaan-massal-mei-1998

Zilcosky, J. (2016). Uncanny encounters: Literature, psychoanalysis, and the end of alterity. Northwestern University Press.

\section{Notes on Contributor}

Anas Ahmadi, Dr., is a lecturer in Indonesian Language and Literature Department, Universitas Negeri Surabaya, Indonesia. His work focuses on literary criticism, psychology of literature, cultural studies, and literature in language teaching. His research interests are literary criticism, psychology of literature, indigenous psychology, cultural studies, ethnic studies, and local culture. ORCID: https://orcid.org/0000-0003-2583-2703 